\title{
Development of an Analytical Methodology for the Determination of Trace Metal Constituents in U-Zr Alloy by ICP-AES
}

\author{
Arijit Sengupta*, B. Rajeswari, R.M. Kadam, and S.V. Godbole \\ Radiochemistry Division, Bhabha Atomic Research Centre, Trombay, Mumbai 400 085, India
}

\section{INTRODUCTION}

Uranium-based binary and ternary alloy fuels are possible candidates for use in advanced fast spectrum reactors (1-4). Amongst these, U-Zr and U-Pu-Zr alloys, owing to their higher heavy atom density, are considered to be potential alloy fuels for meeting the desired burn-up, high breeding ratio ( 1.4), lower doubling time, and high thermal conductivity (516). Several studies have been carried out to understand the thermophysical, mechanical, and metallurgical properties of U-Zr and U-Pu-Zr alloy samples (17-28).

The performance of any fuel in the reactor depends on purity, chemical and physical properties, and isotopic compositions of the constituents of the fuel. Therefore, stringent chemical quality control and quality assurance programs are required to meet the specifications of the fuel as set by the fuel designer before its use in the reactor. Hence, development of a suitable analytical methodology for the estimation of trace constituents in uranium-zirconium (U-Zr) alloy becomes a pre-requisite.

Inductively coupled plasma atomic emission spectrometry (ICPAES), known for its simultaneous multi-element detection capabilities with improved precision, sensitivity, and detection limits has been extensively used as an analytical technique for trace metal assay of nuclear materials (29-41). The present study features the first work of its kind for the trace metal assay of U-Zr alloy samples after chemical

Corresponding author.

E-mail: arijita@barc.gov.in

\section{ABSTRACT}

Since uranium-zirconium $(\mathrm{U}-\mathrm{Zr})$ alloys are one of the advanced fuels for future fast reactors, it is desirable to develop a method for the determination of trace constituents in $\mathrm{U}-\mathrm{Zr}$ alloys as an integral part of chemical quality control of nuclear materials.

A methodology was developed involving the simultaneous and selective extraction of $\mathrm{U}$ and $\mathrm{Zr}$ into the organic phase containing $30 \%$ tributyl phosphate (TBP)$\mathrm{CCl}_{4}$, followed by the analysis of the raffinate for trace metallic constituents by inductively coupled plasma atomic emission spectrometry. The extraction profiles of $\mathrm{U}$ and $\mathrm{Zr}$ at various feed nitric acid concentrations revealed that $7 \mathrm{M} \mathrm{HNO}_{3}$ was the optimum feed acidity for the simultaneous extraction of $\mathrm{U}$ and $\mathrm{Zr}$ using $30 \% \mathrm{TBP}^{-\mathrm{CCl}_{4}}$ as the organic phase.

Due to the emission-rich spectra of $\mathrm{U}$ and $\mathrm{Zr}$, a systematic study on the spectral interferences of $U$ and $\mathrm{Zr}$ on the analytes of interest was carried out which revealed that $10 \mu \mathrm{g} / \mathrm{mL}$ of $\mathrm{U}$ and 1000 $\mu \mathrm{g} / \mathrm{mL}$ of $\mathrm{Zr}$ can be tolerated by the specified analytical wavelengths for the trace level determination of these analytes. Five sequential extractions of $30 \%$ TBP- $\mathrm{CCl}_{4}$ were found to be sufficient to bring down the residual matrix concentration in the raffinate within tolerable limits.

The methodology developed was validated using synthetic samples and found to be satisfactory for the 16 analytes of interest (Al, B, Cd, Co, Cr, Cu, Dy, Eu, $\mathrm{Gd}, \mathrm{Fe}, \mathrm{Mn}, \mathrm{Na}, \mathrm{Ni}, \mathrm{Sm}$, and $\mathrm{Zn}$ ), including common impurities and rare earth elements (REEs), even at trace levels. separation of $\mathrm{U}$ and $\mathrm{Zr}$, followed by analyte determination in the raffinate using ICP-AES. Both $\mathrm{U}$ and $\mathrm{Zr}$, the major constituents of the alloy, have line-rich emission spectra which can lead to spectral interferences during trace metal assay. Therefore, prior chemical separation of the major matrix is a prerequisite for the determination of trace level metal impurities by ICPAES. Generally, for uranium-based nuclear materials, the trace metal determination by ICP-AES is carried out after chemical separation of $U$ using solvent extraction from $\mathrm{HNO}_{3}$ medium, followed by the analysis of the raffinate (30-38). Huff et al. (42) attempted to determine the trace metal impurities in U-Pu-Zr alloy fuel using anion exchange partition chromatography.

In the present work, a methodology for the determination of trace metal constituents in U-Zr alloy was developed by ICP-AES, involving optimization of a method for the simultaneous removal of $\mathrm{U}$ and $\mathrm{Zr}$ by solvent extraction using $100 \mathrm{~mL}$ of $30 \% \mathrm{TBP} / 70 \% \mathrm{CCl}_{4} / \mathrm{HNO}_{3}(1: 1)$, followed by the determination of the trace metals in the raffinate. A systematic study was also carried out to understand the effect of residual $\mathrm{U}$ and $\mathrm{Zr}$ on the determination of the analytes at trace levels which revealed that $10 \mu \mathrm{g} / \mathrm{mL}$ of $\mathrm{U}$ and $1000 \mu \mathrm{g} / \mathrm{mL}$ of $\mathrm{Zr}$ can be tolerated for the estimation of $16 \mathrm{impu}$ rities at trace levels (Al, B, Cd, Co, $\mathrm{Cr}, \mathrm{Cu}, \mathrm{Dy}, \mathrm{Eu}, \mathrm{Gd}, \mathrm{Fe}, \mathrm{Mn}, \mathrm{Na}, \mathrm{Ni}$, $\mathrm{Sm}$, and $\mathrm{Zn}$ ).

The methodology was validated using synthetic samples by adding known amounts of impurities to solutions with known U-Zr compositions. The study was further extended to four real samples. The 
methodology was found to be suitable for the determination of trace metal constituents in $\mathrm{U}-\mathrm{Zr}$ alloy samples.

\section{EXPERIMENTAI}

\section{Instrumentation}

A Jobin-Yvon Model Panorama axial-view ICP spectrometer, equipped with a polychromator with 35 fixed analytical channels and limited sequential facility to select any analytical line within $2.2 \mathrm{~nm}$ of the polychromator lines, was used (Yobin-Yvon, Longjumeau, France). For nebulization, a pneumatic cross-flow nebulizer together with a peristaltic pump was employed with a sample flow rate of $1 \mathrm{~mL} / \mathrm{min}$. The resolution of the spectrometer was $0.028 \mathrm{~nm}$. The main instrumental operating conditions are given in Table I.

\section{Preparation of Standards and Samples}

Suprapur ${ }^{\circledR}$ acids (E. Merck, Darmstadt, Germany) and quartz doubly distilled water were used for preparation of the standards and sample solutions. Multi-element standard solutions were prepared from commercially available SpecPure ${ }^{\circledR}$ solutions (JohnsonMatthey Chemicals Ltd., London, UK) using appropriate dilution with $0.5 \mathrm{M} \mathrm{HNO}_{3}$. These solutions were used for obtaining calibration plots during ICP-AES analysis. A multipoint standardization was carried out using $0.5 \mathrm{M} \mathrm{HNO}_{3}$ as the blank and $0.5,10,20,50$, and $100 \mu \mathrm{g} / \mathrm{mL}$ of the corresponding elemental standard as the higher standards, respectively. High purity $\mathrm{U}_{3} \mathrm{O}_{8}$ and SpecPure $\mathrm{Zr}$ solutions were taken to prepare solutions in the concentration range of $100-1000 \mu \mathrm{g} / \mathrm{mL}$ to monitor the contribution of $U$ and $\mathrm{Zr}$ on the various analyte wavelengths. Similarly, $0.5 \mathrm{M} \mathrm{HNO}_{3}$ served as a reagent blank to monitor any contribution arising from the blank.

\section{Procedure}

To optimize the methodology for the simultaneous extraction of $\mathrm{U}$ and $\mathrm{Zr}$, a systematic study was carried out to obtain the extraction profile by varying the feed $\mathrm{HNO}_{3}$ concentration in the range of 1-8 $\mathrm{M}$ using $30 \% \mathrm{TBP}$ in $\mathrm{CCl}_{4}$ as the organic phase. Five sequential extractions using $100 \mathrm{~mL}$ of $30 \% \mathrm{TBP} / 70 \% \mathrm{CCl}_{4}$ with an aqueous:organic phase (A:O) ratio of $1: 1$ were found to be sufficient for bringing the residual matrix in the raffinate within the tolerance limits. These are the maximum concentrations of the matrix which will not affect the trace level determinations $(10 \mu \mathrm{g} / \mathrm{mL}$ for $\mathrm{U}$ and $1000 \mu \mathrm{g} / \mathrm{mL}$ for $\mathrm{Zr}$ ).

The method was validated using synthetic samples. One gram each of various $\mathrm{U}-\mathrm{Zr}$ alloy samples were dissolved in $10 \mathrm{~mL}$ of a $0.05 \% \mathrm{HF}$ $\mathrm{HNO}_{3}$ mixture (HF $0.005 \mathrm{~mL}$ and $\mathrm{HNO}_{3} 9.995 \mathrm{~mL}$ ). Uranium and $\mathrm{Zr}$

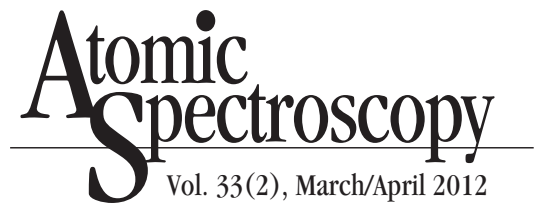

were separated simultaneously from $7 \mathrm{M} \mathrm{HNO}_{3}$ using five extractions of $30 \% \mathrm{TBP}$ in $70 \% \mathrm{CCl}_{4}$ in a ratio $\mathrm{A}: \mathrm{O}=1: 1$, followed by the analysis of the raffinate $(10 \mathrm{~mL}$ for trace constituents).

\section{RESULTS AND DISCUSSION}

\section{Spectral Interference of $\mathrm{U}$ and Zr on Specified Analytical Channels}

SpecPure $\mathrm{U}$ and $\mathrm{Zr}$ solutions were fed to the instrument independently at various concentrations to monitor the specified analytical channels and to understand the spectral interference due to the matrix. It is required that $U$ as well as $\mathrm{Zr}$ are determined along with the other analytes to obtain correction factors at specified concentration levels. The $385.958 \mathrm{~nm}$ and $342.823 \mathrm{~nm}$ lines were chosen for the $\mathrm{U}$ and $\mathrm{Zr}$ determinations, respectively. The interference studies revealed that the effects of $U$ on

TABLE I

Specifications and Operating Conditions of ICP-AES

\begin{tabular}{ll}
\hline Spectrometer & \\
\hline Optical design & $1 \mathrm{~m}$ Czerny Turner \\
Grating & Holographic, 2 ion-etched optical gratings \\
Groove density & 2400 grooves $/ \mathrm{mm}, 4320$ grooves $/ \mathrm{mm}$ \\
Grating size & $110 \mathrm{X} 110 \mathrm{~mm}$ \\
Wavelength range & $120-800 \mathrm{~nm}$ \\
Bandpass & $0.0023 \mathrm{~nm}$ from $120-340 \mathrm{~nm}$ \\
& $0.0046 \mathrm{~nm}$ from $340-800 \mathrm{~nm}$ \\
Thermal regulation & Controlled to $30 \pm 1{ }^{\circ} \mathrm{C}$ \\
\hline RF Generator & \\
\hline Frequency & $40.68 \mathrm{MHz}$ \\
Oscillator & $27.12 \mathrm{MHz}$ \\
Pump & Dual channel $(12 \mathrm{roller})$ \\
Nebulizer & Pneumatic concentric \\
\hline Operating Conditions & \\
\hline Operating power & $1 \mathrm{~kW}$ \\
Ar plasma flow & $13 \mathrm{~L} / \mathrm{min}$ \\
Integration time & $10 \mathrm{~s}$ \\
Reflected power & $<10 \mathrm{~W}$ \\
Sample rate & $1 \mathrm{~mL} / \mathrm{min}$ \\
\hline
\end{tabular}


TABLE II

Spectral Interference of Uranium on Analytes of Interest

\begin{tabular}{lcccc}
\hline Elements & $\begin{array}{c}\text { Wave- } \\
\text { length }\end{array}$ & \multicolumn{3}{c}{ Contribution from U to the } \\
& & \multicolumn{2}{c}{ Specified Analytical Lines } \\
& $(\mathrm{nm})$ & $(10 \mu \mathrm{g} / \mathrm{mL})$ & $\begin{array}{c}\mathrm{U} \\
(100 \mu \mathrm{g} / \mathrm{mL})\end{array}$ & $\begin{array}{c}\mathrm{U} \\
(1000 \mu \mathrm{mL})\end{array}$ \\
\hline $\mathrm{Al}$ & 308.2 & 0.19 & 1.9 & 18.6 \\
$\mathrm{~B}$ & 249.6 & $<0.05$ & 0.21 & 2.4 \\
$\mathrm{Ca}$ & 396.8 & $<0.05$ & $<0.05$ & 0.10 \\
$\mathrm{Cd}$ & 228.8 & $<0.05$ & $<0.05$ & 0.19 \\
$\mathrm{Co}$ & 237.8 & $<0.05$ & 0.17 & 1.5 \\
$\mathrm{Cr}$ & 205.5 & $<0.05$ & $<0.05$ & 0.15 \\
$\mathrm{Cu}$ & 324.7 & $<0.05$ & 0.26 & 2.0 \\
$\mathrm{Dy}$ & 353.1 & $<0.05$ & 0.07 & 0.60 \\
$\mathrm{Eu}$ & 381.9 & $<0.05$ & $<0.05$ & 0.16 \\
$\mathrm{Gd}$ & 342.2 & $<0.05$ & 0.22 & 1.9 \\
$\mathrm{Fe}$ & 259.9 & $<0.05$ & 0.13 & 0.97 \\
$\mathrm{Mn}$ & 257.6 & $<0.05$ & $<0.05$ & 0.23 \\
$\mathrm{Na}$ & 589.5 & $<0.05$ & 0.26 & 2.7 \\
$\mathrm{Ni}$ & 232 & $<0.05$ & 0.24 & 2.6 \\
$\mathrm{Sm}$ & 359.2 & $<0.05$ & 0.3 & 3.2 \\
$\mathrm{Zn}$ & 213.8 & $<0.05$ & $<0.05$ & 0.11 \\
\hline
\end{tabular}

TABLE III

Spectral Interference of Zirconium on Analytes of Interest

\begin{tabular}{|c|c|c|c|c|}
\hline \multirow[t]{2}{*}{ Elements } & \multirow{2}{*}{$\begin{array}{l}\text { Wave- } \\
\text { length } \\
(\mathrm{nm})\end{array}$} & \multicolumn{3}{|c|}{$\begin{array}{l}\text { Contribution from } \mathrm{Zr} \text { to the } \\
\text { Specified Analytical Lines }\end{array}$} \\
\hline & & $\begin{array}{c}\mathrm{Zr} \\
(100 \mu \mathrm{g} / \mathrm{mL})\end{array}$ & $\begin{array}{c}\mathrm{Zr} \\
(500 \mu \mathrm{g} / \mathrm{mL})\end{array}$ & $\begin{array}{c}\mathrm{Zr} \\
(1000 \mu \mathrm{g} / \mathrm{mL})\end{array}$ \\
\hline $\mathrm{Al}$ & 308.2 & $<0.05$ & $<0.05$ & $<0.05$ \\
\hline B & 249.6 & $<0.05$ & $<0.05$ & $<0.05$ \\
\hline $\mathrm{Ca}$ & 396.8 & $<0.05$ & $<0.05$ & $<0.05$ \\
\hline $\mathrm{Cd}$ & 228.8 & $<0.05$ & $<0.05$ & $<0.05$ \\
\hline Co & 237.8 & $<0.05$ & 0.15 & 0.32 \\
\hline $\mathrm{Cr}$ & 205.5 & $<0.05$ & $<0.05$ & $<0.05$ \\
\hline $\mathrm{Cu}$ & 324.7 & $<0.05$ & $<0.05$ & 0.07 \\
\hline Dy & 353.1 & $<0.05$ & $<0.05$ & $<0.05$ \\
\hline $\mathrm{Eu}$ & 381.9 & $<0.05$ & $<0.05$ & $<0.05$ \\
\hline Gd & 342.2 & $<0.05$ & $<0.05$ & 0.09 \\
\hline $\mathrm{Fe}$ & 259.9 & $<0.05$ & $<0.05$ & $<0.05$ \\
\hline Mn & 257.6 & $<0.05$ & $<0.05$ & $<0.05$ \\
\hline $\mathrm{Na}$ & 589.5 & 0.07 & 0.45 & 0.87 \\
\hline $\mathrm{Ni}$ & 232 & $<0.05$ & $<0.05$ & 0.09 \\
\hline Sm & 359.2 & $<0.05$ & $<0.05$ & 0.07 \\
\hline $\mathrm{Zn}$ & 213.8 & $<0.05$ & $<0.05$ & $<0.05$ \\
\hline
\end{tabular}

the specified analytical lines were more pronounced in comparison to $\mathrm{Zr}$. In case of $\mathrm{U}$, a $10 \mu \mathrm{g} / \mathrm{mL}$ concentration of $U$ was found to be tolerable for the trace determination of the analytes of interest at specified lines, except for $\mathrm{Al}$, which needs to be corrected (for $308.20 \mathrm{~nm}$ line) with $0.19 \mu \mathrm{g} / \mathrm{mL}$ per $\mu \mathrm{g} / \mathrm{mL}$ of $\mathrm{U}$ (Table II). For $\mathrm{Zr}$, $1000 \mu \mathrm{g} / \mathrm{mL}$ of $\mathrm{Zr}$ can be tolerated for most of the specified analytical lines at trace level determination, except for $\mathrm{Co}$ at $237.80 \mathrm{~nm}$ and $\mathrm{Na}$ at $589.50 \mathrm{~nm}$ (Table III). For the above two lines (Co at $237.80 \mathrm{~nm}$ and $\mathrm{Na}$ at $589.50 \mathrm{~nm}), 100 \mu \mathrm{g} / \mathrm{mL}$ of $\mathrm{Zr}$ is the limit of tolerance.

\section{Optimization of Methodology}

The variation of distribution (D) coefficients $\mathrm{D}_{\mathrm{U}}$ and $\mathrm{D}_{\mathrm{Zr}}$ for $\mathrm{U}$ and $\mathrm{Zr}$ with variations in feed $\mathrm{HNO}_{3}$ concentration are shown in Figure 1. It was found that the $D_{U}$ value increased with an increase in acidity and attained a plateau beyond

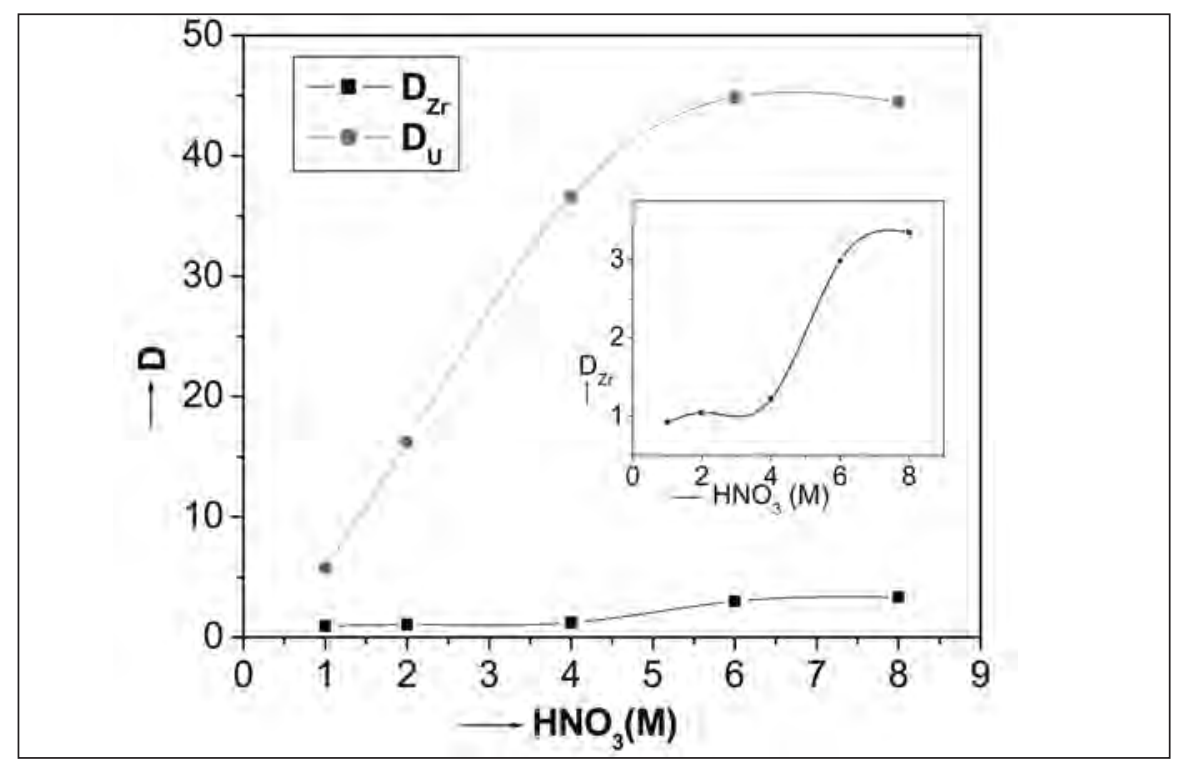

Fig. 1. Extraction profile of $U$ and $\mathrm{Zr}$ in various feed acidity.

$6 \mathrm{M}$ with $\mathrm{D}_{\mathrm{U}} \sim 44$, while $\mathrm{D}_{\mathrm{Zr}}$ increased beyond $4 \mathrm{M}$ and leveled off at $7 \mathrm{M}$ acidity with $\mathrm{D}_{\mathrm{Zr}} \sim 3.3$. This suggested that for the simulta- neous extraction of $\mathrm{U}$ and $\mathrm{Zr}$ from $\mathrm{U}-\mathrm{Zr}$ alloy, $7 \mathrm{M}$ feed acidity would be optimum for matrix separation using the $\mathrm{TBP}^{-\mathrm{CCl}_{4}}$ system. System- 


\section{Atomic Mpectroscopy \\ 1 Vol. 33(2), March/April 2012}

TABLE IV

Analytical Data Obtained for Synthetic Sample \#1 (U-2\% Zr)

\begin{tabular}{cccc}
\hline Elements & \multicolumn{3}{c}{$\begin{array}{c}\text { Synthetic Sample With the Composition } \\
\text { of U-2\%Zr With Known Amounts of } \\
\text { Added Elements } \\
\text { Estimated } \\
(\mu \mathrm{g} / \mathrm{mL})\end{array}$} \\
$\begin{array}{cccc}\text { Added } \\
(\mu \mathrm{g} / \mathrm{mL})\end{array}$ & $\begin{array}{c}\text { Recovery } \\
(\%)\end{array}$ \\
\hline $\mathrm{Al}$ & 0.5 & $0.40 \pm 0.04$ & 80 \\
$\mathrm{~B}$ & 0.5 & $0.52 \pm 0.05$ & 104 \\
$\mathrm{Ca}$ & 0.5 & $0.58 \pm 0.07$ & 116 \\
$\mathrm{Cd}$ & 0.5 & $0.44 \pm 0.04$ & 88 \\
$\mathrm{Co}$ & 0.5 & $0.42 \pm 0.04$ & 84 \\
$\mathrm{Cr}$ & 0.5 & $0.49 \pm 0.03$ & 98 \\
$\mathrm{Cu}$ & 0.5 & $0.45 \pm 0.04$ & 90 \\
$\mathrm{Dy}$ & 0.5 & $0.45 \pm 0.04$ & 90 \\
$\mathrm{Eu}$ & 0.5 & $0.48 \pm 0.04$ & 96 \\
$\mathrm{Gd}$ & 0.5 & $0.46 \pm 0.05$ & 92 \\
$\mathrm{Fe}$ & 0.5 & $0.52 \pm 0.05$ & 104 \\
$\mathrm{Mn}$ & 0.5 & $0.50 \pm 0.04$ & 100 \\
$\mathrm{Na}$ & 0.5 & $0.51 \pm 0.04$ & 102 \\
$\mathrm{Ni}$ & 0.5 & $0.47 \pm 0.04$ & 94 \\
$\mathrm{Sm}$ & 0.5 & $0.48 \pm 0.05$ & 96 \\
$\mathrm{Zn}$ & 0.5 & $0.49 \pm 0.04$ & 98 \\
\hline
\end{tabular}

atic studies revealed that five contacts of $30 \% \mathrm{TBP}_{-} \mathrm{CCl}_{4}$ with $\mathrm{A}: \mathrm{O}=1: 1$ is required to make the concentration of $\mathrm{U}$ and $\mathrm{Zr}$ in the raffinate at tolerable limits.

\section{Analysis of Synthetic and Real Samples for the Determination of Trace Metals}

Synthetic samples were prepared with the composition of U-2\% Zr (synthetic sample \#1), U-6\% Zr (synthetic sample \#2), and $U-10 \% \mathrm{Zr}$ (synthetic sample \#3), and adding known amounts $(5 \mu \mathrm{g} / \mathrm{mL})$ of the analytes of interest. After separation of the major matrix below tolerable limits, the raffinate was analyzed for 16 trace metal constituents (Tables IV, V, and VI). It was observed that for most of the elements the \% recovery was satisfactory. For Ca and B (which are common contaminants), an increase in estimated value might be due to process pickup.

Four real samples (obtained from the Radiometallurgical Division, Bhabha Atomic Research Centre, Trombay, India) were analyzed having the composition of $\mathrm{U}-10 \% \mathrm{Zr}, \mathrm{U}-6 \% \mathrm{Zr}, \mathrm{U}-2 \% \mathrm{Zr}$, and U-metal using the optimized method (five contacts of $30 \% \mathrm{TBP} / 70 \% \mathrm{CCl}_{4}$, $\mathrm{A}: \mathrm{O}=1: 1$, to bring $\mathrm{U}$ and $\mathrm{Zr}$ in the raffinate below the tolerance level, followed by determination of the trace constituents in the raffinate. It was found that $\mathrm{Cr}, \mathrm{Mn}$, $\mathrm{Ni}$, and $\mathrm{Cu}$ were present in the $\mathrm{U}$ metal and in $\mathrm{U}-2 \% \mathrm{Zr}$, while $\mathrm{Zn}$ and $\mathrm{Fe}$ were present in all of the samples, except for U-10\%Zr. All of the critical elements (Eu, Sm,
TABLE V

Analytical Data Obtained for Synthetic Sample \#2 (U-6\% Zr)

\begin{tabular}{cccc}
\hline Elements & \multicolumn{3}{c}{$\begin{array}{c}\text { Synthetic Sample With the Composition } \\
\text { of U-6\%Zr With Known Amounts of } \\
\text { Added Elements } \\
\text { Estimated } \\
(\mu \mathrm{g} / \mathrm{mL})\end{array}$} \\
$\begin{array}{cccc}\text { Added } \\
(\mu \mathrm{g} / \mathrm{mL})\end{array}$ & $\begin{array}{c}\text { Recovery } \\
(\%)\end{array}$ \\
\hline $\mathrm{Al}$ & 0.5 & $0.41 \pm 0.04$ & 82 \\
$\mathrm{~B}$ & 0.5 & $0.58 \pm 0.05$ & 116 \\
$\mathrm{Ca}$ & 0.5 & $0.58 \pm 0.07$ & 116 \\
$\mathrm{Cd}$ & 0.5 & $0.46 \pm 0.04$ & 92 \\
$\mathrm{Co}$ & 0.5 & $0.47 \pm 0.04$ & 94 \\
$\mathrm{Cr}$ & 0.5 & $0.42 \pm 0.03$ & 84 \\
$\mathrm{Cu}$ & 0.5 & $0.41 \pm 0.04$ & 82 \\
$\mathrm{Dy}$ & 0.5 & $0.41 \pm 0.04$ & 82 \\
$\mathrm{Eu}$ & 0.5 & $0.40 \pm 0.04$ & 80 \\
$\mathrm{Gd}$ & 0.5 & $0.49 \pm 0.05$ & 98 \\
$\mathrm{Fe}$ & 0.5 & $0.52 \pm 0.05$ & 104 \\
$\mathrm{Mn}$ & 0.5 & $0.40 \pm 0.04$ & 80 \\
$\mathrm{Na}$ & 0.5 & $0.43 \pm 0.04$ & 86 \\
$\mathrm{Ni}$ & 0.5 & $0.47 \pm 0.04$ & 94 \\
$\mathrm{Sm}$ & 0.5 & $0.46 \pm 0.05$ & 92 \\
$\mathrm{Zn}$ & 0.5 & $0.42 \pm 0.04$ & 84 \\
\hline
\end{tabular}

TABLE VI

Analytical Data Obtained for Synthetic Sample \#3 (U-10\% Zr)

\begin{tabular}{cccc}
\hline Elements & \multicolumn{3}{c}{$\begin{array}{c}\text { Synthetic Sample With the Composition } \\
\text { of U-10\%Zr With Known } \\
\text { Added Elements } \\
\text { Estimated } \\
(\mu \mathrm{g} / \mathrm{mL})\end{array}$} \\
$\begin{array}{cccc}\text { Added } \\
(\mu \mathrm{g} / \mathrm{mL})\end{array}$ & $\begin{array}{c}\text { Recovery } \\
(\%)\end{array}$ \\
\hline $\mathrm{Al}$ & 0.5 & $0.44 \pm 0.04$ & 88 \\
$\mathrm{~B}$ & 0.5 & $0.55 \pm 0.05$ & 110 \\
$\mathrm{Ca}$ & 0.5 & $0.54 \pm 0.07$ & 108 \\
$\mathrm{Cd}$ & 0.5 & $0.46 \pm 0.04$ & 92 \\
$\mathrm{Co}$ & 0.5 & $0.48 \pm 0.04$ & 96 \\
$\mathrm{Cr}$ & 0.5 & $0.42 \pm 0.03$ & 84 \\
$\mathrm{Cu}$ & 0.5 & $0.40 \pm 0.04$ & 80 \\
$\mathrm{Dy}$ & 0.5 & $0.45 \pm 0.04$ & 90 \\
$\mathrm{Eu}$ & 0.5 & $0.43 \pm 0.04$ & 86 \\
$\mathrm{Gd}$ & 0.5 & $0.47 \pm 0.05$ & 94 \\
$\mathrm{Fe}$ & 0.5 & $0.42 \pm 0.05$ & 82 \\
$\mathrm{Mn}$ & 0.5 & $0.50 \pm 0.04$ & 100 \\
$\mathrm{Na}$ & 0.5 & $0.53 \pm 0.04$ & 106 \\
$\mathrm{Ni}$ & 0.5 & $0.47 \pm 0.04$ & 94 \\
$\mathrm{Sm}$ & 0.5 & $0.45 \pm 0.05$ & 90 \\
$\mathrm{Zn}$ & 0.5 & $0.45 \pm 0.04$ & 90 \\
\hline
\end{tabular}


Gd, Dy, and Cd) were found to be below the limits of detection, except $\mathrm{B}$, which was found to be present in the $\mathrm{U}-2 \% \mathrm{Zr}$ and $\mathrm{U}-6 \% \mathrm{Zr}$ samples. The overall impurities were found to be $6.2,23,284.5$, and $83.9 \mathrm{ppm}$ in $\mathrm{U}-10 \% \mathrm{Zr}, \mathrm{U}-6 \% \mathrm{Zr}$, $\mathrm{U}-2 \% \mathrm{Zr}$, and $\mathrm{U}$ metal, respectively.

\section{CONCLUSION}

Attempts were made to develop a method for the determination of trace metal constituents in uraniumzirconium (U-Zr) alloy samples. The contribution of $\mathrm{U}$ and $\mathrm{Zr}$ on the commonly used analytical lines of the analytes of interest suggested that $10 \mu \mathrm{g} / \mathrm{mL}$ of $\mathrm{U}$ and $1000 \mu \mathrm{g} / \mathrm{mL}$ of $\mathrm{Zr}$ can be tolerated in the aqueous phase after extraction. Extraction profiles of $\mathrm{U}$ and $\mathrm{Zr}$ with varying $\mathrm{HNO}_{3}$ molarity indicated that for the simultaneous extraction of $\mathrm{U}$ and $\mathrm{Zr}$ from the feed to the tolerable concentrations in the raffinate, five sequential extractions of $30 \%$ tributyl phosphate (TBP) $/ 70 \% \mathrm{CCl}_{4}(\mathrm{~A}: \mathrm{O}=1: 1)$ and a feed acidity of $7 \mathrm{M} \mathrm{HNO}_{3}$ were required.

This method was successfully applied to the determination of 16 trace metal constituents ( $\mathrm{Al}, \mathrm{B}$, $\mathrm{Cd}, \mathrm{Co}, \mathrm{Cr}, \mathrm{Cu}, \mathrm{Dy}, \mathrm{Eu}, \mathrm{Gd}, \mathrm{Fe}, \mathrm{Mn}$, $\mathrm{Na}, \mathrm{Ni}, \mathrm{Sm}$, and $\mathrm{Zn}$ ) in $\mathrm{U}-\mathrm{Zr}$ alloy samples and was validated using synthetic samples.

Received December 5, 2011.

\section{REFERENCES}

1. W.N. Beck, F.L. Brown, B.J. Koprowski, and J.H., Kittel, Trans. Amer. Nucl. Soc. 10(1), 106 (1967).

2. P.A. Tucker, D.E. Etter, and J.M. Gebhart, Trans. Amer. Nucl. Soc. 11, 99 (1968).

3. D.R. O'Boyle and A.E. Dwight, Nucl. Mater. 17, 720 (1970).

4. P.S.K.Lam and W.P. Barthold, Trans. Amer. Nucl. Soc. 27, 753 (1977).
5. A.G. Hins, D.A. Kraft, and H.F Jelinek, Trans. Amer. Nucl. Soc. 30, 310 (1978).

6. L. Leibowitz, , E. Veleckis, R.A. Blomquist, and A.D.Pelton, J. Nucl. Mater. 154(1), 145 (1988).

7. C.E. Lahm, D.L. Porter, and R.G. Pahl, J. Metals 40(7), A86 (1988).

8. G.L. Hofman, P R. Gahl, C.E. Lahm, and D.L. Porter, J. Metals, 40(7), A86 (1988).

9. R.G. Pahl, C.E. Lahm, D.L. Porter, and G.L. Hofman, ,J. Metals 40(7), A71 (1988).

10. R.I. Sheldon and D.E. Peterson, Bull. Alloy Phase Diagrams 10(2), 165 ( 1989).

11. D.E. Peterson and E.M. Foltyn, Bull. Alloy Phase Diagrams 10(2), 160 (1989).

12. W.G. Steele, A.R. Wazzan, and D. Okrent, Nucl. Eng. Des. 113(3), 289 (1989).

13. D.L. Porter, C.E. Lahm, and R.G. Pahl, Metall. Trans. A, 21(7), 1871 (1990).

14. R.G. Pahl, D.L. Porter, C.E. Lahm, and G.L. Hofman, Metall. Trans. A 21(7), 1863 (1990).

15. L. Gerard, G.L. Hofman, R.G. Pahl, C.E. Lahm, and D.L. Porter, Metall. Trans. A 21(3), 517 (1990).

16. M. Kurata, Calphad. 23(3-4), 305 (1999).

17. M. Ishida, T. Ogata, and M Kinoshita, Nucl. Techol. 104(1), 37 (1993).

18. J. Rest, J. Nucl. Mater. 207, 192 (1993).

19. D.C. Crawford, C.E. Lahm, H. Tsai, and R.G. Pahl, J. Nucl. Mater. 204, 157 (1993).

20. H. Okamoto, J. Phase Equilib. 14(3), 400 (1993).

21. C. Sari, C.T. Walker, M. Kurata, and T. Inoue, J. Nucl. Mater. 208, 201 (1994).

22. M. Kurata and T. Inoue Sari, J. Nucl. Mater. 208, 144 (1994).

23. Jr. D.D. Keiser and M.C. Petri, J. Nucl. Mater. 240, 51 (1996).

24. M.C. Petri and M.A. Dayananda, J. Nucl. Mater. 240, 131 (1997).

25. O.A. Alekseev, E.A. Smirnov, and A.A. Shmakov, At. Ener. 84(4), 260 (1998).
26. Y.H. Sohn, M.A. Dayananda, G.L. Hofman, R.V. Strain, and S.L Hayes, J. Nucl. Mater. 279, 317 (2000).

27. Y.S. Kim, G.L. Hofman, S.L. Hayes, and Y.H. Sohn, J. Nucl. Mater. 327, 27 (2004).

28. M. Iizuka, K. Kinoshita, and T. Koyama, J. Phys. Chem. Solids 66(2-4), 427 (2005).

29. M. Gopalkrishnan, K. Radhakrishnan, P.S. Dhami, V.T. Kulkarni, M.V. Joshi, A.B. Patwardhan, A. Ramanujam, and J.N. Mathur, Talanta 44(2), 169 (1997).

30. K. Satyanarayana and S.Durani, J. Radioanal. and Nucl. Chem. 285(3), 659 (2010)..

31. P.L. Mahanta, G. Chakrapani, and R. Radhamani, At. Spectrosc. 31(1), 21 (2010).

32. S Chandramouleeswaran and J.C. Upadya, Exploration and Res. for Atomic Minerals 19, 54 (2009).

33. L W.-Yiu and S.-L Zeng, Yuanzineng Kexue Jishu/At. Energy Science and Technology 38(5), 424 (2004).

34. B. Rajeswari, B.A. Dhawale, T.R. Bangia, J.N. Mathur, and A.G. Page, J. of Radioanal. and Nucl. Chem. 254(3), 479 (2002).

35. A.A. Argekar, M.J. Kulkarni, J.N. Mathur, and A.G. Page, Talanta 56(4), 591 (2002).

36. C. Mahan, S. Bonchin, D. Figg, D. Gcrth, and C. Collier, J. of Anal. At. Spectrom. 15(8), 929 (2000).

37. R.K. Malhotra, and K. Satyanarayana, Talanta 50(3), 601 (1999).

38. S. Marin, S. Cornejo, C. Jara, and N. Duran, Fresenius' J. of Anal. Chem. 355(5-6), 680 (1996).

39. E.A. Huff, Spectrochim. Acta, Part B: Atomic Spectroscopy, 42 (1-2), 275 (1987).

40. P.J. Purohit, N. Goyal, S.K. Thulasidas, A.G. Page, and M.D. Sastry, Spectrochim. Acta, Part B: Atomic Spectroscopy, 55(8), 1257 (2000).

41. E.A. Huff and D.L. Bowers, Appl. Spectrosc. 43(2), 223 (1989).

42. E.A. Huff and S.J. Kulpa, Anal. Chem. 38(7), 939 (1966). 